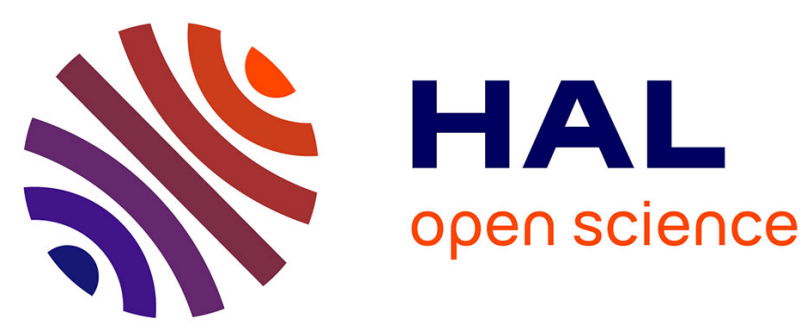

\title{
Zobellia roscoffensis sp. nov. and Zobellia nedashkovskayae sp. nov., two flavobacteria from the epiphytic microbiota of the brown alga Ascophyllum nodosum, and emended description of the genus Zobellia
}

Tristan Barbeyron, Manon Thiébaud, Nolwen Le Duff, Marjolaine Martin, Erwan Corre, Gwenn Tanguy, Micheline Vandenbol, François Thomas

\section{To cite this version:}

Tristan Barbeyron, Manon Thiébaud, Nolwen Le Duff, Marjolaine Martin, Erwan Corre, et al.. Zobellia roscoffensis sp. nov. and Zobellia nedashkovskayae sp. nov., two flavobacteria from the epiphytic microbiota of the brown alga Ascophyllum nodosum, and emended description of the genus Zobellia. International Journal of Systematic and Evolutionary Microbiology, 2021, 71 (8), pp.004913. 10.1099/ijsem.0.004913 . hal-03357314

\author{
HAL Id: hal-03357314 \\ https://hal.science/hal-03357314
}

Submitted on 30 Sep 2021

HAL is a multi-disciplinary open access archive for the deposit and dissemination of scientific research documents, whether they are published or not. The documents may come from teaching and research institutions in France or abroad, or from public or private research centers.
L'archive ouverte pluridisciplinaire $\mathbf{H A L}$, est destinée au dépôt et à la diffusion de documents scientifiques de niveau recherche, publiés ou non, émanant des établissements d'enseignement et de recherche français ou étrangers, des laboratoires publics ou privés. 
Zobellia roscoffensis sp. nov. and Zobellia nedashkovskayae sp. nov., two flavobacteria

2 from the epiphytic microbiota of the brown alga Ascophyllum nodosum, and emended

\section{description of the genus Zobellia}

Tristan Barbeyron ${ }^{1, *}$, Manon Thiébaud ${ }^{1}$, Nolwen Le Duff ${ }^{1}$, Marjolaine Martin $^{2}$, Erwan Corre ${ }^{3}$, Gwenn Tanguy ${ }^{4}$, Micheline Vandenbol ${ }^{2}$, François Thomas, ${ }^{1, *}$

Running Title: Zobellia roscoffensis sp. nov., Zobellia nedashkovskayae sp. nov.

\section{Author affiliations:}

${ }^{1}$ CNRS, Sorbonne Université, Integrative Biology of Marine Models (LBI2M), Station Biologique de Roscoff, 29680 Roscoff, Brittany, France; ${ }^{2}$ University of Liège, Gembloux Agro-Bio Tech, Microbiology and Genomic Laboratory, TERRA building, avenue de la Faculté 2b, 5030 Gembloux, Belgium; ${ }^{3}$ CNRS, Sorbonne Université, FR2424, ABiMS, Station Biologique de Roscoff, 29680, Roscoff, Brittany France; ${ }^{4}$ CNRS, Sorbonne Université, FR2424, Genomer, Station Biologique de Roscoff, 29680 Roscoff, Brittany France

*Correspondence: Tristan Barbeyron, barboun@sb-roscoff.fr; François Thomas, fthomas@sb-roscoff.fr

Keywords: Zobellia roscoffensis; Zobellia nedashkovskayae; Flavobacteriaceae; polysaccharide; macroalgal microbiome

Abbreviations: ANI, average nucleotide identity; dDDH, digital DNA-DNA hybridization; GGDC, Genome-Genome Distance Calculator; ML, maximum-likelihood; MP, maximumparsimony; NJ, neighbour-joining.

Subject category: New Taxa: Bacteroidetes 
26 The Genbank/EMBL/DDBJ accession numbers for the 16S rRNA gene sequences are as

27 follows: MW114830 for strain Asnod1-F08 ${ }^{\mathrm{T}}$, MW114831 for strain Asnod2-B02-B,

28 MW114832 for strain Asnod2-B07-B ${ }^{\mathrm{T}}$, MW114833 for strain Asnod3-E08-A.

29 The Genbank/ENA/DDBJ accession numbers for the genome sequences are as follows:

30 JADDXT000000000 for strain Asnod1-F08 ${ }^{\mathrm{T}}$, JADDXS000000000 for strain Asnod2-B02-B,

31 JADDXR000000000 for strain Asnod2-B07-B ${ }^{\mathrm{T}}$, JADDXQ000000000 for strain Asnod3-E08-

32 A.

33 Three supplementary figures and three supplementary tables are available in the online

34 version of this article.

35 


\section{Abstract}

Four marine bacterial strains were isolated from the thallus of the brown alga Ascophyllum nodosum collected in Roscoff, France. Cells were Gram-stain-negative, strictly aerobic, nonflagellated, gliding, rod-shaped and grew optimally at $25-30{ }^{\circ} \mathrm{C}$, at $\mathrm{pH} 7-8$ and with $2-4 \%$ $\mathrm{NaCl}$. Phylogenetic analyses of their 16S rRNA gene sequences showed that the bacteria were affiliated to the genus Zobellia (family Flavobacteriaceae, Phylum Bacteroidetes). The four strains exhibited 97.8 - 100\% 16S rRNA gene sequence similarity values among themselves, $97.9-99.1 \%$ with the type strains of Zobellia amurskyensis $\mathrm{KMM} 3526^{\mathrm{T}}$ and Z. laminariae KMM $3676^{\mathrm{T}}$, and less than $99 \%$ with other species of the genus Zobellia. The DNA G+C content of the four strains ranged from 36.7 to $38.1 \mathrm{~mol} \%$. Average Nucleotide Identity (ANI) and digital DNA-DNA hybridization (Genome-to-Genome Distance Calculator, GGDC) methods between the new strains and other members of the genus Zobellia showed values of $76.4-88.9 \%$, and below $38.5 \%$, respectively. Phenotypic, phylogenetic and genomic analyses show that the four strains are distinct from species of the genus Zobellia with validly published names. They represent two novel species of the genus Zobellia, for which the names Zobellia roscoffensis sp. nov. and Zobellia nedashkovskayae sp. nov. are proposed with Asnod1-F08 ${ }^{\mathrm{T}}\left(\mathrm{RCC} 6906^{\mathrm{T}}=\mathrm{KMM} 6823^{\mathrm{T}}=\mathrm{CIP} 111902^{\mathrm{T}}\right)$ and Asnod2-B07-B ${ }^{\mathrm{T}}(\mathrm{RCC}$ $\left.6908^{\mathrm{T}}=\mathrm{KMM} 6825^{\mathrm{T}}=\mathrm{CIP} 111904^{\mathrm{T}}\right)$, respectively, as the type strains. 
The genus Zobellia was proposed by Barbeyron et al. [1] and contains Gram-negative, aerobic, gliding, bacteria that produce flexirubin-type pigments. At the time of writing, the genus Zobellia comprises 5 validly named species, Zobellia galactanivorans, Zobellia uliginosa [1], Zobellia amurskyensis, Zobellia laminariae and Zobellia russellii [2], all isolated from marine environments. Z. galactanivorans, a species isolated from the red alga Delesseria sanguinea (Hudson) J. V. Lamouroux, 1813, was chosen as the type species.

During a previous study of the surface microbiota of the brown alga Ascophyllum nodosum (Linnaeus) Le Jolis 1863, 324 bacterial strains were isolated [3]. The taxonomic position of four isolates was investigated in the present study using a polyphasic approach, including some genomic data deduced from their draft genome, whole-genome comparison using the average nucleotide identity (ANI) and dDDH (digital DNA-DNA hybridization) methods, phenotypic and physiological analyses. Based on these results, we report the description of two novel species of the genus Zobellia, for which the names Zobellia roscoffensis sp. nov. and Zobellia nedashkovskayae sp. nov. are proposed.

The isolates investigated in this study were obtained by sampling healthy A. nodosum plants collected in the English Channel from the foreshore (48 $\left.43^{\prime} 36.07^{\prime \prime} \mathrm{N},-3^{\circ} 59^{\prime} 22.96^{\prime \prime} \mathrm{W}\right)$ in Roscoff (Brittany, France) at the end of March 2014 [3]. Strains Asnod1-F08 ${ }^{\mathrm{T}}$, Asnod2-B02B, Asnod2-B07- $\mathrm{B}^{\mathrm{T}}$ and Asnod3-E08-A were isolated by swabbing algal surfaces with sterile cotton tips and then inoculating plates of marine agar 2216 (Difco).

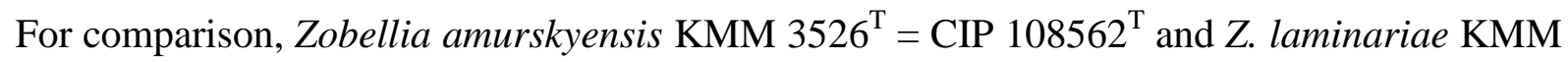

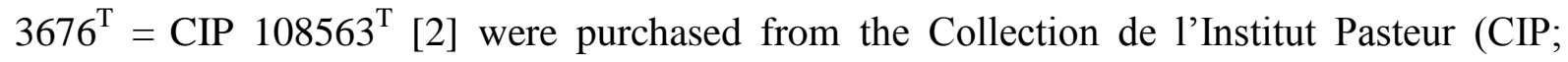
France) and used as related type strains. Except for the temperature, $\mathrm{pH}$ and $\mathrm{NaCl}$ ranges of growth, Z. amurskyensis KMM $3526^{\mathrm{T}}$ and Z. laminariae KMM $3676^{\mathrm{T}}$ were studied in parallel with the four new strains for all phenotypic tests and for quinone, fatty acid and polar lipid analyses. All strains were routinely cultivated on ZoBell medium 2216E [4], either liquid or 
solidified with $1.5 \%(\mathrm{w} / \mathrm{v})$ agar. Pure cultures were stored at $-80{ }^{\circ} \mathrm{C}$ in the culture medium containing $20 \%(\mathrm{v} / \mathrm{v})$ glycerol. All experiments were performed in triplicate. Growth was evaluated in ZoBell agar plates at 4, 9, 11, 12, 13, 15, 17, 18, 20, 22, 24, 30, 37, 40, 42, 45 and $48{ }^{\circ} \mathrm{C}$. The optimal $\mathrm{pH}$ value for growth was determined at $25{ }^{\circ} \mathrm{C}$ in ZoBell broth with $\mathrm{pH}$ values adjusted by using $100 \mathrm{mM}$ of the following buffers: MES for $\mathrm{pH}$ 5.0; Bis Tris for $\mathrm{pH}$ 5.5, 6.0, 6.5, 7.0 and 7.5; Tris for $\mathrm{pH}$ 8.0, 8.5 and 9.0; CHES for $\mathrm{pH} 9.5$ and CAPS for $\mathrm{pH}$ 10.0, 10.5 and 11.0. The effect of $\mathrm{NaCl}$ on growth was determined at $25^{\circ} \mathrm{C}$ and at $\mathrm{pH} 8$ in ZoBell broth prepared with distilled water containing $0,0.5,1.0,2.0,3.0,4.0,5.0,6.0,8.0$, $10,12,15,17,20$ and $25 \% \mathrm{NaCl}$. To test the influence of other salts on growth, the same $\mathrm{NaCl}$ range was used in ZoBell broth prepared with artificial seawater without $\mathrm{NaCl}$ but containing $6.3 \mathrm{~g} \mathrm{MgSO}_{4} \mathrm{l}^{-1}, 4.2 \mathrm{~g} \mathrm{MgCl}_{2} \mathrm{l}^{-1}$, and $0.7 \mathrm{~g} \mathrm{KCl}^{-1}$.

Cell morphology and gliding motility were investigated on wet mounts of an exponential phase ZoBell broth culture at $25^{\circ} \mathrm{C}$, by using phase-contrast microscopy on an Olympus BX60 instrument (Olympus, Tokyo, Japan). The Ryu non-staining KOH method [5] was used to determine the Gram type. Production of flexirubin was assessed by flooding a $4 \mathrm{~d}$ plate culture with $20 \%(\mathrm{w} / \mathrm{v})$ potassium hydroxide followed by the observation of changes in colony colour from yellow to red or brown [6]. Colony iridescence was assayed on $3 \mathrm{~d}$ plate cultures on R2A-agar (Difco) using a STEMI 2000-C stereomicroscope (Zeiss) equipped with a KC 15000 LCP light source and a 455170 polarizing analyzer.

Oxidase activity was assayed using small pieces of 3MM paper (Whatman) soaked in the reagent $\mathrm{N}, \mathrm{N}, \mathrm{N}^{\prime}, \mathrm{N}^{\prime}$-tetramethyl-p-phenylenediamine dihydrochloride (bioMérieux). Catalase activity was assayed by mixing one colony from a ZoBell agar plate with a drop of hydrogen peroxide $(3 \%, \mathrm{v} / \mathrm{v})$. Amylase activity was assayed on $0.2 \%(\mathrm{w} / \mathrm{v})$ soluble starch ZoBell agar plates. DNase activity was detected on DNA agar (Difco) prepared with seawater. Amylase and DNase activities were revealed by flooding the plates with Lugol's solution or $1 \mathrm{M} \mathrm{HCl}$, 
respectively. The degradation of Tween compounds (1\%, v/v) was assayed in ZoBell agar according to Smibert \& Krieg [7]. Agarase, $\kappa$-carrageenase and 1 -carrageenase activities were tested by inoculating ZoBell media solidified with (per litre): 15 g agar (Sigma-Aldrich, ref. A7002), 10 g א-carrageenan (X-6913; Danisco) or 20 g -carrageenan (X-6905; Danisco) respectively. ZoBell media solidified with alginate was made using with the calcium carbonate / gluconolactone method [8]. Strains were considered positive when colonies liquefied or produced craters in the solidified substrate. Moreover, agarase activity was revealed by flooding the plates with Lugol's solution. Additional phenotypic characterizations 113 were performed using API $20 \mathrm{E}$, API $20 \mathrm{NE}$, API 50CH and API ZYM strips according to the manufacturer's instructions (bioMérieux) except that API AUX medium and API $50 \mathrm{CHB} / \mathrm{E}$ medium were adjusted to $2.5 \% \mathrm{NaCl}$. All strips were inoculated with cell suspensions in artificial seawater and incubated at $25{ }^{\circ} \mathrm{C}$ for $48 \mathrm{~h}$. The ability to use carbohydrates as sole 117 carbon and energy sources was also tested in marine minimal medium [9] containing $2 \mathrm{~g} \mathrm{l}^{-1}$ of 118 the following sugars (all from Sigma-Aldrich unless otherwise stated): D-glucose, D119 galactose, D-fructose, L-fucose, D-mannose, L-arabinose, L-rhamnose, D-xylose, lactose, 120 sucrose, maltose, D-raffinose, D-mannitol, glucomannan (Megazyme), galactan (arabic gum), 121 galactomannan from carob seeds (Megazyme), arabinan (Megazyme), arabinoxylane 122 (Megazyme), xylan, xyloglucan (Megazyme), amylopectine (Merck), pectin (from apple), 123 lichenin (Megazyme), laminarin (Goëmar), agar, porphyrin (extracted from Porphyra sp.), $\kappa-$ 124 carrageenin (Danisco), l-carrageenin (Danisco), $\lambda$-carrageenin (Danisco), acid alginic 125 (Danisco), fucoidin from Ascophyllum nodosum (kindly provided by Algues et Mer) and 126 ulvan (kindly provided by Pr. Bruno Moerschbacher, University of Münster, Germany).

127 Sensitivity to antibiotics was tested by the disc-diffusion method on ZoBell agar plates and 128 using antibiotic discs (Bio-Rad) containing ( $\mu$ g per disc, unless otherwise stated): penicillin G 129 (10 IU), ampicillin (10), carbenicillin (100), oxacillin (5), streptomycin (500), kanamycin 
130 (30), chloramphenicol (30), tetracycline (30), lincomycin (15), bacitracin (130), rifampicin

131 (30), vancomycin (30), trimethoprime/sulfamethoxazole (1.25/23.75), colistin (50),

132 gentamicin (15), neomycin (30), nalidixic acid (30), polymixin (50), erythromycin (15). The

133 effects of the antibiotics on cell growth were assessed after $48 \mathrm{~h}$ of incubation at $25{ }^{\circ} \mathrm{C}$, and

134 susceptibility was scored based on the diameter of the clear zone around the disc.

135 Analysis of respiratory quinones $[10,11]$, fatty acids $[12,13]$ and polar lipids $[14,15]$ were 136 performed on freeze-dried cultures of strains Asnod1-F08 ${ }^{\mathrm{T}}$, Asnod2-B02-B, Asnod2-B07-B ${ }^{\mathrm{T}}$, 137 Asnod3-E08-A and of Z. amurskyensis KMM $3526^{\mathrm{T}}$ and Z. laminariae KMM $3676^{\mathrm{T}}$ grown at 138 room temperature in ZoBell medium 2216E, by Susanne Verbarg and Dr. Brian Tindall from 139 the DSMZ Identification Service, Braunschweig, Germany.

140 Genomic DNA was extracted from strains Asnod1-F08 ${ }^{\mathrm{T}}$, Asnod2-B02-B, Asnod2-B07-B ${ }^{\mathrm{T}}$ and 141 Asnod3-E08-A using the DNeasy UltraClean Microbial kit (QIAGEN). Sequencing libraries 142 were prepared using the Nextera XT DNA kit (Illumina) and sequenced using Illumina MiSeq 143 v3 PE300, resulting in 5,312,862 quality-filtered reads for Asnod1-F08 ${ }^{\mathrm{T}}$, 5,534,396 for Asnod2-B02-B, 4,493,736 for Asnod2-B07-B ${ }^{\mathrm{T}}$ and 2,037,244 for Asnod3-E08-A (Table S1). Reads were assembled using SPAdes v3.11 [16] and scaffolds were built using MeDuSa v1.6 146 [17] using the closed genome of Z. galactanivorans Dsij ${ }^{\mathrm{T}}$ as backbone. In silico gap filling 147 was performed using GapCloser v1.12 [18]. The final assemblies consist of 2 scaffolds (6 contigs) for Asnod1-F08 ${ }^{\mathrm{T}}, 6$ scaffolds (11 contigs) for Asnod2-B02-B, 3 scaffolds (5 contigs) 149 for Asnod2-B07-B ${ }^{\mathrm{T}}$ and 9 scaffolds (13 contigs) for Asnod3-E08-A. Completeness was 150 checked with CheckM v1.0.11 [19] by searching for 571 lineage-specific marker genes, and 151 was estimated at $100 \%$ for the four strains (Table S1).

152 The 16S rRNA gene sequence was amplified by PCR using pure genomic DNA as template 153 and the bacteria-specific primer pair, 8F [20] and 1492R [21]. PCR reactions were typically 154 prepared in a volume of $25 \mu \mathrm{l}$ containing 10-100 ng template, $0.4 \mu \mathrm{M}$ each specific primer, 

$250 \mu \mathrm{M}$ each dNTP, $0.1 \mathrm{mg}$ BSA, 1X GoTaq buffer (Promega) and 1.25 U GoTaq DNA polymerase (Promega). PCR amplification was performed as previously described [22]. PCR products were purified using the Exostar kit according to the manufacturer's protocol (GE Healthcare) and sequenced using BigDye Terminator V3.1 (Applied Biosystems) and an ABI PRISM 3130xl Genetic Analyzer automated sequencer (Applied Biosystems/Hitachi). Chargaff's coefficient $(\mathrm{G}+\mathrm{C}$ content $)$ of the genomic DNA of strains Asnod1-F08 ${ }^{\mathrm{T}}$, Asnod2B02-B, Asnod2-B07-B ${ }^{T}$ and Asnod3-E08-A was deduced from the draft genome sequence and expressed as the molar percentage of guanine + cytosine. The nucleotide sequences of the 16S rRNA gene deduced from the draft genomes were compared to those obtained by direct sequencing of PCR-amplified products, showing high identity for each strain $(99.85 \%$ for Asnod1-F08 ${ }^{\mathrm{T}}$, 99.71\% for Asnod2-B02-B, 99.86\% for Asnod2-B07-B ${ }^{\mathrm{T}}$ and $99.93 \%$ for Asnod3-E08-A). Genome-extracted 16S rRNA sequences for the four new strains were aligned with sequences of the 16S rRNA genes from all valid species of the genus Zobellia and from some species of the closest genera using the software MAFFT version 7 with the LINS-I strategy [23]. The alignment was then manually refined and phylogenetic analyses, using the neighbour-joining (NJ) [24], maximum-parsimony (MP) [25] and maximumlikelihood (ML) [26] methods, were performed using the MEGA 6 package [27]. The different phylogenetic trees were built from a multiple alignment of 41 sequences and 1435 positions. For the NJ algorithm, the evolutionary model Kimura Two Parameters [28] was used. The ML tree was calculated using the evolutionary model Kimura Two Parameters with a discrete Gamma distribution to model evolutionary rate differences among sites (4 categories). This substitution model was selected through submission of the alignment to the online server IQ-TREE (http://iqtree.cibiv.univie.ac.at/) [29]. The MP tree was obtained using the Subtree-Pruning-Regrafting algorithm [30]. Bootstrap analysis (1000 replicates) was performed to provide confidence estimates for the phylogenetic tree topologies [31]. A 
phylogenomic tree was constructed with FastTree MP based on a concatenated alignment of

1812573 translated protein-coding genes from the core genome of Zobellia species (50\% amino

182 acid identity, 80\% coverage) using custom scripts. Pairwise comparisons of 16S rRNA gene 183 sequences were made by using the database EzBioCloud

184 (https://www.ezbiocloud.net/identify) [32] and the FASTA software [33]. Genomic 185 relatedness was investigated by comparing the new isolates genome sequence with those of 186 the type strains of other Zobellia species using ANI 187 (http://jspecies.ribohost.com/jspeciesws/\#analyse) [34-36] and dDDH via the online server

188 Genome to Genome Distance Calculator 2.1 (GGDC; http://ggdc.dsmz.de/distcalc2.php) [37].

189 The results from GGDC analysis were obtained from the alignment method Blast+ and the 190 formula 2 (sum of all identities found in HSPs / by overall HSP length; HSP: High-scoring 191 segment pairs) for incomplete genome sequences [38, 39]. Exploration of carbohydrate active 192 enzyme-coding genes in the genomes of the strains Asnod1-F08 ${ }^{\mathrm{T}}$, Asnod2-B02-B, Asnod2193 B07-B ${ }^{\mathrm{T}}$, Asnod3-E08-A and comparison with Z. amurskyensis KMM $3526^{\mathrm{T}}$ and $Z$.

194 laminariae $\mathrm{KMM} 3676^{\mathrm{T}}$ [40] was carried out via the online server Microscope from the 195 French National Sequencing Center (http://www.genoscope.cns.fr/agc/microscope/mage) [41] 196 and the CAZy database (www.cazy.org) [42].

197 Phylogenetic analyses of $16 \mathrm{~S}$ rRNA genes of species from a subset of the family 198 Flavobacteriaceae showed that strains Asnod1-F08 ${ }^{\mathrm{T}}$, Asnod2-B02-B, Asnod2-B07-B ${ }^{\mathrm{T}}$ and 199 Asnod3-E08-A belong to the genus Zobellia (Figs 1 and S1). The 16S rRNA genes from 200 Asnod1-F08 $^{\mathrm{T}}$ and Asnod2-B02-B were included in a clade containing the type strains of $Z$. 201 amurskyensis $\mathrm{KMM} 3526^{\mathrm{T}}$ and Z. laminariae $\mathrm{KMM} 3676^{\mathrm{T}}$ while the $16 \mathrm{~S}$ rRNA genes from 202 Asnod2-B07-B ${ }^{T}$ and Asnod3-E08-A were distantly related to type strains of $Z$. 203 galactanivorans $\mathrm{Dsij}^{\mathrm{T}}$ and Z. uliginosa $553^{\mathrm{T}}$ (Figs 1 and $\mathrm{S} 1$ ). The best pairwise comparison 204 scores with 16S rRNA gene from the strains Asnod1-F08 ${ }^{\mathrm{T}}$ and Asnod2-B02-B (1525 bp for 
205 both), were obtained with Zobellia galactanivorans Dsij ${ }^{\mathrm{T}}$ and Z. uliginosa $553^{\mathrm{T}}(99.0 \%$;

206 Table S2, available in the online version of this article) and with Z. galactanivorans Dsij ${ }^{\mathrm{T}}$ and 207 Z. uliginosa $553^{\mathrm{T}}(98.8 \%$; Table S2), respectively. From the $16 \mathrm{~S}$ rRNA sequence of Asnod2208 B07-B ${ }^{\mathrm{T}}$ and Asnod3-E08-A (1523 for both), the best scores were obtained with Z. laminariae 209 KMM $3676^{\mathrm{T}}$ (99.1\%; Table S2) for both strains. The 16S rRNA gene sequence similarities 210 between the four new strains and other Zobellia species were in the range of $97.4 \%$ with $\mathrm{Z}$. 211 russellii $\mathrm{KMM} 3677^{\mathrm{T}}$ and $98.5 \%$ with Z. amurskyensis $\mathrm{KMM} 3526^{\mathrm{T}}$ (Table S2). The draft 212 genomes of strains Asnod1-F08 ${ }^{\mathrm{T}}$, Asnod2-B02-B, Asnod2-B07-B ${ }^{\mathrm{T}}$ and Asnod3-E08-A were 213 sequenced. The genomic sizes were between 4,941,018 (Asnod2-B07-B $\left.{ }^{\mathrm{T}}\right)$ and 5,025,849 214 nucleotides (Asnod3-E08-A) and the Chargaff's coefficients (G+C content) were between $21536.7 \%$ for Asnod3-E08-A and $37.7 \%$ for Asnod2-B02-B. Analysis of a phylogenomic tree 216 based on 2573 genes from the core genome of sequenced Zobellia strains showed that 217 Asnod2-B07-B ${ }^{\mathrm{T}}$ and Asnod3-E08-A formed a clade with Z. laminariae KMM $3676^{\mathrm{T}}$, while 218 Asnod1-F08 $^{\mathrm{T}}$ and Asnod2-B02-B were distant to all other strains (Fig S2). ANI and GGDC 219 methods (formula 2) for the new isolates, when compared with the valid species of Zobellia, 220 were less than $89 \%$ and less than $38.5 \%$ respectively ( $88.9 \%$ and $38.3 \%$ with Z. laminariae 221 KMM $3676^{\mathrm{T}}$; Table S3). As the normally accepted thresholds of species delineation for ANI 222 and GGDC are $95 \%$ and 70\%, respectively [34, 36, 43, 44], these values suggest that strains 223 Asnod1-F08 $^{\mathrm{T}}$, Asnod2-B02-B, Asnod2-B07-B ${ }^{\mathrm{T}}$ and Asnod3-E08-A do not belong to any of 224 the valid species of the genus Zobellia. In addition, the genomes of the new isolates showed 225 the highest ANI and GGDC percentages with those of Z. laminariae KMM $3676^{\mathrm{T}}$ and $Z$. 226 amurskyensis $\mathrm{KMM} 3526^{\mathrm{T}}$, suggesting that these two species were closest to the new isolates 227 (Table S3). The strains Z. laminariae KMM $3676^{\mathrm{T}}$ and Z. amurskyensis $\mathrm{KMM}^{2} 326^{\mathrm{T}}$ were 228 therefore studied in parallel with the new isolates. Finally, the ANI and GGDC percentages 229 between Asnod1-F08 ${ }^{\mathrm{T}}$ and Asnod2-B02-B (97.5 and 81.6\% respectively) showed that these 
230

231

232

233

234

235

two strains represent a new species, for which the name Zobellia roscoffensis sp. nov. is proposed (Table S3). Similarly, the ANI and GGDC percentages between Asnod2-B07-B ${ }^{T}$ and Asnod3-E08 (97.6 and 82.1\%, respectively) showed that these two strains represent a new species, for which the name Zobellia nedashkovskayae sp. nov. is proposed.

The strains Asnod1-F08 ${ }^{\mathrm{T}}$, Asnod2-B02-B, Asnod2-B07-B ${ }^{\mathrm{T}}$ and Asnod3-E08-A cultivated on ZoBell medium 2216E showed yellow-orange colonies of $1 \mathrm{~mm}$ in diameter strongly attached to agar after three days at $25^{\circ} \mathrm{C}$. The flexirubin-type pigments were present for the four strains. A spreading aspect of colonies was observed only for the strains Asnod1-F08 ${ }^{\mathrm{T}}$ and Asnod2-B02-B. A weak iridescence was observed only for Asnod1-F08 ${ }^{\mathrm{T}}$ and Asnod2-B02-B. The cells were Gram stain negative. Under the microscope, they appeared as rods attached to the glass of the slide or coverslip and showed gliding mobility.

The four strains Asnod1-F08 ${ }^{\mathrm{T}}$, Asnod2-B02-B, Asnod2-B07-B ${ }^{\mathrm{T}}$ and Asnod3-E08-A used the non-gelling agaroid porphyrin, as sole carbon source (Table 1). Surprisingly, agar, although hydrolysed by the strains Asnod1-F08 ${ }^{\mathrm{T}}$, Asnod2-B02-B and Z. amurskyensis KMM $3526^{\mathrm{T}}$, is not used as sole carbon source by any of the strains including Z. amurskyensis KMM $3526^{\mathrm{T}}$ and Z. laminariae $\mathrm{KMM} 3676^{\mathrm{T}}$ (Table 1). This result might be explained by the presence of the gene agaC in the genomes of Asnod1-F08 ${ }^{\mathrm{T}}$, Asnod2-B02-B and Z. amurskyensis KMM $3526^{\mathrm{T}}$ only. An outer-membrane AgaC ortholog was recently characterized in $Z$. galactanivorans Dsij $^{\mathrm{T}}$ (Genbank accession CAZ98402), and shown to be an agarase active on complex agars [45]. The studied strains might miss one or several gene(s) for utilization of agar as sole carbon source, such as agaA (CAZ98338 in Z. galactanivorans Dsij ${ }^{\mathrm{T}}$ ) that is absent from their genomes. None of the tested carrageenins were hydrolysed or used as carbon and energy source (Table 1). This observation is consistent with the absence of genes cgkA and $\operatorname{cgiA}$ encoding a $\kappa$ - and $\mathrm{t}$-carrageenase, respectively, in the six studied genomes whereas the genome of the carrageenolytic Z. galactanivorans Dsij $^{\mathrm{T}}$ contains one $c g k A$ 
strains analysed in this study feature the complete operon responsible for the assimilation of

Zobellia strains in this study possess between 4 to 8 genes encoding alginate lyases, alginic acid was degraded and used as the sole carbon source by Asnod2-B07-B ${ }^{\mathrm{T}}$, Asnod3-E08-A and Z. amurskyensis KMM $3526^{\mathrm{T}}$ only (Table 1). Furthermore, the strains Asnod2-B07-B ${ }^{\mathrm{T}}$ and Asnod3-E08-A liquefied the alginate while Z. amurskyensis $\mathrm{KMM} 3526^{\mathrm{T}}$ only formed a crater. This difference in behaviour could be due to the absence of the gene alyAl, encoding a secreted endo-alginate lyase in Z. galactanivorans Dsij $^{\mathrm{T}}$ (CAZ95239) [48], in the genome of Z. amurskyensis $\mathrm{KMM} 3526^{\mathrm{T}}$, while alyA1 is present in the genomes of strains Asnod2-B07$265 \mathrm{~B}^{\mathrm{T}}$ and Asnod3-E08-A. The strains Asnod1-F08 ${ }^{\mathrm{T}}$ and Asnod2-B02-B did not degrade or utilize 266 alginic acid as unique carbon source (Table 1). This might be due to the absence of a gene encoding the alginate-specific SusD-like lipoprotein (CAZ96770 in Z. galactanivorans Dsij ${ }^{\mathrm{T}}$ ), involved in the binding and internalisation of oligo-alginates [49]. Finally, it remains 269 unexplained why Z. laminariae $\mathrm{KMM} 3676^{\mathrm{T}}$ does not degrade alginic acid, since no 270 difference in the alginate lyase gene content could be observed compared to Z. amurskyensis $271 \mathrm{KMM} 3526^{\mathrm{T}}$. Starch was hydrolysed and used as sole carbon source by Z. amurskyensis 272 KMM $3526^{\mathrm{T}}$, the only strain that showed a hydrolysis area on soluble starch ZoBell agar 273 plates (Table 1). This result is consistent with the presence of the susA gene encoding an outer 274 membrane $\alpha$-amylase in its genome, while it is absent from the strains Asnod1-F08 ${ }^{\mathrm{T}}$, Asnod2275 B02-B, Asnod2-B07-B ${ }^{\mathrm{T}}$, Asnod3-E08-A and Z. laminariae KMM 3676 ${ }^{\mathrm{T}}$. Although all strains 276 possess malS, encoding an $\alpha$-amylase of the cytoplasmic membrane, susA might be necessary 277 to use starch as unique carbon source. The other physiological features of Asnod1-F08 ${ }^{\mathrm{T}}$, 278 Asnod2-B02-B, Asnod2-B07-B ${ }^{\mathrm{T}}$, Asnod3-E08-A compared with Z. amurskyensis KMM $2793526^{\mathrm{T}}$ and Z. laminariae KMM $3676^{\mathrm{T}}$ are listed in Table 1. 
The six strains were resistant to penicillin, oxacillin, polymyxin $\mathrm{B}$, bacitracin, colistin, gentamicin, neomycin, kanamycin, trimethoprime/sulfamethoxazole and nalidixic acid, and were sensitive to rifampicin. Asnod2-B07-B ${ }^{\mathrm{T}}$, Asnod3-E08-A, Z. amurskyensis KMM $3526^{\mathrm{T}}$ 283 284 and Z. laminariae $\mathrm{KMM} 3676^{\mathrm{T}}$ were sensible to lyncomycin and carbenicillin, while Asnod1F08 ${ }^{\mathrm{T}}$ and Asnod2-B02-B were resistant to these antibiotics.

285 The major fatty acids (>10\% of the total fatty acids) of strains Asnod1-F08 ${ }^{\mathrm{T}}$, Asnod2-B02-B, 286 Asnod2-B07-B ${ }^{\mathrm{T}}$ and Asnod3-E08-A were iso- $\mathrm{C}_{15: 0}(>20 \%)$, iso- $\mathrm{C}_{17: 0} 3-\mathrm{OH}(>18 \%)$, iso-C $\mathrm{C}_{15: 1}$ 287 $\mathrm{G}(>10 \%)$ and those contained in summed feature $3\left(>10 \% ; \mathrm{C}_{16: 1} \omega 7 c\right.$ and/or iso- $\left.\mathrm{C}_{15: 0} 2 \mathrm{OH}\right)$

288 (Table 2). These fatty acid profiles were similar to those of Z. amurskyensis KMM $3526^{\mathrm{T}}$ and 289

Z. laminariae KMM $3676^{\mathrm{T}}$ (Table 2) and confirmed previous results [2]. From all strains, the respiratory quinone was menaquinone-6 (MK-6). The major polar lipids of all strains were unidentified lipids and aminolipids and phosphatidylethanolamine (Fig. S2). Z. amurskyensis $\mathrm{KMM} 3526^{\mathrm{T}}$ and Z. laminariae $\mathrm{KMM} 3676^{\mathrm{T}}$ were characterized by the presence of two phosphatidylethanolamine spots. In conclusion, phenotypic characterizations and phylogenetic analysis using $16 \mathrm{~S}$ rRNA gene sequences together with whole-genome pairwise comparisons show that strains Asnod1-F08 ${ }^{\mathrm{T}}$, Asnod2-B02-B on one hand, and Asnod2-B07$\mathrm{B}^{\mathrm{T}}$ and Asnod3-E08-A on the other hand represent two novel species in the genus Zobellia, for which the names Zobellia roscoffensis sp. nov. and Zobellia nedashkovskayae sp. nov. are proposed, respectively.

\section{EMENDED DESCRIPTION OF THE GENUS ZOBELLIA BARBEYRON ET AL. 2001}

The description of the genus is as given by Barbeyron et al. [1] with the following modified features. The hydrolysis of galactans from red seaweeds such as agar, $\kappa$ - carrageenan and $1-$ carrageenan and of alginic acid from brown seaweeds depends on the species. The $\mathrm{G}+\mathrm{C}$ content of the genomic DNA ranges from 36.7 to $43 \mathrm{~mol} \%$. 
305 Zobellia roscoffensis (ros.coff.en'sis. N.L. fem. adj. roscoffensis referring to Roscoff in 306 Brittany, France, where the type strain was isolated).

307 Cells are Gram-stain-negative, aerobic, chemoorganotrophic, heterotrophic, and rod-shaped, 308 approximately $0.5 \mu \mathrm{m}$ in diameter and 2.0-4.0 $\mu \mathrm{m}$ in length; a few cells greater than $4 \mu \mathrm{m}$ in 309 length may occur. Flagella are absent. Prosthecae and buds are not produced. Colonies on 310 ZoBell agar are orange-coloured, convex, circular and mucoid in consistency and 2.0-3.0 mm 311 in diameter strongly attached to agar after incubation for 3 days at $25^{\circ} \mathrm{C}$. A weak iridescence 312 is visible on R2A agar after 3 days at $18^{\circ} \mathrm{C}$. Growth in ZoBell broth occurs from 4 to $40{ }^{\circ} \mathrm{C}$ 313 (optimum, $25^{\circ} \mathrm{C}$ ), at $\mathrm{pH} 5.5$ to 8.5 (optimum $\mathrm{pH} 7.5$ ) and in the presence of 2 to $6 \% \mathrm{NaCl}$ 314 (optimum, $2 \%$ ). In presence of magnesium and $\mathrm{KCl}$, the growth also occurs with 0 and $1 \%$ $315 \mathrm{NaCl}$. Positive for the gliding motility and the flexirubin-type pigment production. Nitrate is reduced. $\beta$-galactosidase, oxidase- and catalase-positive. DNA, aesculin, Tween 20, 60 (for

317 the type strain only) and 80 and agar are hydrolysed, but Tween 40, gelatin (for the type strain 318 only), starch, $\kappa$-carrageenan, $\mathbf{\imath - c a r r a g e e n a n}$ and alginic acid are not. D-glucose, D-galactose, 319 D-fructose, rhamnose, N-acetyl-glucosamine, L-fucose (weakly for the type strain), raffinose sucrose, D-maltose, lactose, L-arabinose, mannose, xylose, mannitol, xylan and porphyrin are utilized as carbon and energy sources, but caprate, adipate, citrate, gluconate, malate, 322 phenylacetate, glucomannan, galactomannan, arabinan, arabinoxylan, xyloglucan, laminarin, 323 amylopectine, agar, $\kappa-$, 1 - and $\lambda$-carrageenan, ulvan, fucoidin (Ascophyllum nodosum), alginic 324 acid and pectin (apple) are not. Acid is produced from D-glucose, D-galactose, D-fructose, 325 mannose, D-arabinose, rhamnose, L-fucose, D-tagatose, D-Lyxose methyl-D326 mannopyranoside, methyl-D-glucopyranoside, $N$-acetyl-glucosamine, amygdaline, arbutine, 327 salicine, D-cellobiose, D-lactose, D-melibiose, D-sucrose, D-trehalose, D-Turanose and D328 maltose, but not from L-arabinose, D-ribose, D-xylose, L-sorbose, D-melezitose, L-xylose, D- 
329

330

331

332

333

334

335

fucose, methyl-D-xylopyranoside, glycerol, inositol, D-mannitol, D-sorbitol, adonitol, L- and D-arabitol, dulcitol, erythritol, xylitol, gentiobiose, raffinose, inulin, starch, glycogen, gluconate, 2-ketogluconate and 5-ketogluconate. Negative for indole and $\mathrm{H}_{2} \mathrm{~S}$ production and for arginine dihydrolase, tryptophan deaminase, urease, lysine decarboxylase, ornithine decarboxylase activities. In the API ZYM system, activities from acid phosphatase, alkaline phosphatase, esterase lipase (C8), leucine arylamidase, valine arylamidase, cystine arylamidase, trypsin, $\alpha$-glucosidase, $\beta$-glucosidase and naphthol-AS-BI-phosphohydrolase are present, but activities from lipase (C14), $\alpha$-chymotrypsin, $\beta$-glucuronidase and $\alpha$-fucosidase are absent. The only lipoquinone detected is MK- 6 . The major fatty acids ( $>10 \%$ of the total fatty acids) are iso- $\mathrm{C}_{15: 0}$, iso- $\mathrm{C}_{17: 0} 3-\mathrm{OH}$, iso- $\mathrm{C}_{15: 1} \mathrm{G}$ and summed feature $3\left(\mathrm{C}_{16: 1} \omega 7 c\right.$ and/or iso- $\mathrm{C}_{15: 0}$ 2OH). The major polar lipids are phosphatidylethanolamine and unknown aminolipids. The DNA G+C content is $37.6-37.7 \mathrm{~mol} \%$.

The type strain Asnod1-F08 ${ }^{\mathrm{T}}\left(\mathrm{RCC} 6906^{\mathrm{T}}=\mathrm{KMM} 6823^{\mathrm{T}}=\mathrm{CIP} 111902^{\mathrm{T}}\right)$ and the strain Asnod2-B02-B (RCC 6907 = KMM 6824 = CIP 111903) were isolated from Ascophyllum nodosum surface microbiota. The Genbank/EMBL/DDBJ accession number for the $16 \mathrm{~S}$ rRNA gene sequence of strains Asnod1-F08 ${ }^{\mathrm{T}}$ and Asnod2-B02-B are MW114830 and MW114831, respectively. The Genbank/ENA/DDBJ accession number for the genome sequence of strains Asnod1-F08 ${ }^{\mathrm{T}}$ and Asnod2-B02-B are JADDXT000000000 and JADDXS000000000 respectively.

\section{DESCRIPTION OF ZOBELLIA NEDASHKOVSKAYAE SP. NOV.}

Zobellia nedashkovskayae (ne.dash.kovs'ka.yae N.L. gen. n. nedashkovskayae in honour of Olga Nedashkovskaya for her great contribution to the study of marine Bacteroidetes).

Cells are Gram-stain-negative, aerobic, chemoorganotrophic, heterotrophic, and rod-shaped, approximately $0.5 \mu \mathrm{m}$ in diameter and 2.0-4.0 $\mu \mathrm{m}$ in length; a few cells greater than $4 \mu \mathrm{m}$ in length may occur. Flagella are absent. Prosthecae and buds are not produced. Colonies on 
ZoBell agar are orange yellow-coloured, convex, circular and mucoid in consistency and 2.0-

$3553.0 \mathrm{~mm}$ in diameter strongly attached to agar after incubation for 3 days at $25{ }^{\circ} \mathrm{C}$. Growth in 356 ZoBell broth occurs from 4 to $40{ }^{\circ} \mathrm{C}$ (optimum, $25-30{ }^{\circ} \mathrm{C}$ ), at $\mathrm{pH} 5.5$ to 8.0 (optimum $\mathrm{pH} 7.5$ ) 357 and in the presence of 3 to $6 \% \mathrm{NaCl}$ (optimum, $2 \%$ ). In presence of magnesium and $\mathrm{KCl}$, the 358 growth also occurs with $1 \% \mathrm{NaCl}$. Positive for the gliding motility and the flexirubin-type 359 pigment production. Nitrate is reduced. $\beta$-galactosidase, oxidase- and catalase-positive. DNA, 360 aesculin, Tween 20, 40, 60 and 80 (for the type strain only) and alginic acid are hydrolysed, 361 but gelatin, starch, agar, $\kappa$-carrageenan and -carrageenan are not. D-glucose, D-galactose, D362 fructose, rhamnose, raffinose sucrose, D-maltose, lactose, L-arabinose, mannose, xylose, 363 mannitol, laminarin, porphyrin, fucoidin (Ascophyllum nodosum) and alginic acid are utilized as carbon and energy sources, but L-fucose, $\mathrm{N}$-acetyl-glucosamine, caprate, adipate, citrate, 365 gluconate, malate, phenylacetate, glucomannan, galactomannan, arabinan, arabinoxylan, xyloglucan, xylan, amylopectine, agar, $\kappa-, ~ l-$ and $\lambda$-carrageenan, ulvan and pectin (apple) are not. Acid is produced from D-glucose, D-galactose, D-fructose, mannose, L-arabinose, rhamnose, D-xylose, D-Lyxose, methyl-D-mannopyranoside, methyl-D-glucopyranoside, $N$ acetyl-glucosamine, D-mannitol, amygdaline, arbutine, salicine, D-cellobiose, D-lactose, Dsucrose, D-trehalose, D-Turanose and D-maltose, but not from D-arabinose, D-ribose, L371 sorbose, D-melezitose, L-xylose, D-fucose, L-fucose, D-tagatose, methyl-D-xylopyranoside, 372 glycerol, inositol, D-sorbitol, adonitol, L- and D-arabitol, dulcitol, erythritol, xylitol, D373 melibiose, gentiobiose, raffinose, inulin, starch, glycogen, gluconate, 2-ketogluconate and 5374 ketogluconate. Negative for indole and $\mathrm{H}_{2} \mathrm{~S}$ production and for arginine dihydrolase, 375 tryptophan deaminase, urease, lysine decarboxylase, ornithine decarboxylase activities. In the 376 API ZYM system, activities from acid phosphatase, alkaline phosphatase, esterase lipase 377 (C8), leucine arylamidase, valine arylamidase, cystine arylamidase, trypsin, $\alpha$-chymotrypsin, $378 \alpha$-glucosidase, $\beta$-glucosidase and naphthol-AS-BI-phosphohydrolase are present, but 
379

380

381 fatty acids (>10\% of the total fatty acids) are iso- $\mathrm{C}_{15: 0}$, iso- $\mathrm{C}_{17: 0} 3-\mathrm{OH}$, iso- $\mathrm{C}_{15: 1} \mathrm{G}$ and 382 summed feature $3\left(\mathrm{C}_{16: 1} \omega 7 c\right.$ and/or iso- $\left.\mathrm{C}_{15: 0} 2 \mathrm{OH}\right)$. The major polar lipids are 383 phosphatidylethanolamine and unknown aminolipids. The DNA G+C content is $36.7-36.8$ $384 \mathrm{~mol} \%$.

385 The type strain Asnod2-B07-B ${ }^{\mathrm{T}}\left(\mathrm{RCC} 6908^{\mathrm{T}}=\mathrm{KMM} 6825^{\mathrm{T}}=\mathrm{CIP} 111904^{\mathrm{T}}\right)$ and the strain 386 Asnod3-E08-A (RCC 6909 = KMM 6826 = CIP 111905) were isolated from Ascophyllum 387 388 389 390 391 392 393 394 395 396 397 398 399 400 401 facilities of the Genomer platform, which is part of the Biogenouest core facility network. The 402 authors are grateful to Dr. Gurvan Michel for initial discussions on the project, to Dr. 
403 Bernhard Schink for his advice on Latin grammar and to Dr. Sébastien Bridel for his help 404 with the construction of the phylogenomic tree.

405

406

Funding information

407 This work was supported by the French ANR investment expenditure program IDEALG 408 (grant agreement ANR-10- BTBR-04) and the French ANR project ALGAVOR (grant 409 agreement ANR-18-CE02-0001-01).

410

411

\section{Conflicts of interest}

412 The authors declare that there are no conflicts of interest.

413

414 References

415 1. Barbeyron T, L'Haridon S, Corre E, Kloareg B, Potin P. Zobellia galactanovorans 416 gen. nov., sp. nov., a marine species of Flavobacteriaceae isolated from a red alga, and classification of [Cytophaga] uliginosa (ZoBell and Upham 1944) Reichenbach 1989

2. Nedashkovskaya OI, Suzuki M, Vancanneyt M, Cleenwerck I, Lysenko AM, et al. Zobellia amurskyensis sp. nov., Zobellia laminariae sp. nov. and Zobellia russellii sp. nov., novel marine bacteria of the family Flavobacteriaceae. Int J Syst Evol Microbiol 2004;54:1643-8.

423 3. Martin M, Barbeyron T, Martin R, Portetelle D, Michel G, et al. The Cultivable Surface Microbiota of the Brown Alga Ascophyllum nodosum is Enriched in Macroalgal-Polysaccharide-Degrading Bacteria. Front Microbiol 2015;6:1-14. 
426 4. Zobell C. Studies on marine bacteria I The cultural requirements of heterotrophic aerobes. J Mar Res 1941;4:42-75.

428 5. Powers EM. Efficacy of the Ryu nonstaining KOH technique for rapidly determining gram reactions of food-borne and waterborne bacteria and yeasts. Appl Environ Microbiol 1995;61:3756-3758.

6. Reichenbach H, Kleinig H, Achenbach H. The pigments of Flexibacter elegans: Novel and chemosystematically useful compounds. Arch Microbiol 1974;101:131-144.

433 7. Smibert R, Krieg N. General characterization. In: Gerhardt P, Murray R, Costilow R, Nester E, Wood W, et al. (editors). Manual of Methods for General Bacteriology. Washington, DC., USA: American Society for Microbiology; 1981. pp. 409-443.

8. Draget KI, Ostgaard K, Smidsrød O. Alginate-based solid media for plant tissue culture. Appl Microbiol Biotechnol 1989;31:79-83.

438 9. Thomas F, Barbeyron T, Michel G. Evaluation of reference genes for real-time 439 quantitative PCR in the marine flavobacterium Zobellia galactanivorans. J Microbiol Methods 2011;84:61-6.

441 10. Tindall BJ. A comparative study of the lipid composition of Halobacterium saccharovorum from various sources. Syst Appl Microbiol 1990;13:128-130.

443 11. Tindall B. Lipid composition of Halobacterium lacusprofundi. FEMS Microbiol Lett 1990;66:199-202.

12. Miller L. A single derivatization method for bacterial fatty acid methyl esters including hydroxy acids. J Clin Microbiol 1982;16:584-586. 
447 13. Kuykendall L, Roy M, O'Neill J, Devine T. Fatty acids, antibiotic resistance, and deoxyribonucleic acid homology groups of Bradyrhizobium japonicum. Int J Syst Bacteriol 1988;38:358-361.

450

451

452

453

454

455

456

457

458

459

460

14. Bligh E, Dyer W. A rapid method of total lipid extraction and purification. Can J Biochem Physiol 1959;37:911-917.

15. Tindall B, Sikorski J, Smibert R, Kreig N. Phenotypic characterization and the principles of comparative systematics. In: Reddy C, Beveridge T, Breznak J, Marzluf G, Schmidt T, et al. (editors). Methods for General and Molecular Microbiology. Washington, DC., USA: ASM Press; 2007. pp. 330-393.

16. Bankevich A, Nurk S, Antipov D, Gurevich AA, Dvorkin M, et al. SPAdes: A New Genome Assembly Algorithm and Its Applications to Single-Cell Sequencing. $J$ Comput Biol 2012;19:455-477.

17. Bosi E, Donati B, Galardini M, Brunetti S, Sagot MF, et al. MeDuSa: A multi-draft based scaffolder. Bioinformatics 2015;31:2443-2451.

18. Luo R, Liu B, Xie Y, Li Z, Huang W, et al. SOAPdenovo2: An empirically improved memory-efficient short-read de novo assembler. Gigascience 2012;1:1-6.

19. Parks DH, Imelfort M, Skennerton CT, Hugenholtz P, Tyson GW. CheckM: Assessing the quality of microbial genomes recovered from isolates, single cells, and metagenomes. Genome Res 2015;25:1043-1055.

20. Hicks R, Amann R, Stahl D. Dual staining of natural bacterioplankton with 4',6diamidino-2-phenylindole and fluorescent oligonucleotide probes targeting kingdomlevel 16S rRNA sequences. Appl Environ Microbiol 1992;58:2158-2163. 
21. Kane M, Poulsen L, Stahl D. Monitoring the enrichment and isolation of sulfatereducing bacteria by using oligonucleotide hybridization probes designed from environmentally derived 16S rRNA sequences. Appl Environ Microbiol 1993;59:682686.

22. Barbeyron T, Carpentier F, L'Haridon S, Schüler M, Michel G, et al. Description of Maribacter forsetii sp. nov., a marine Flavobacteriaceae isolated from North Sea water, and emended description of the genus Maribacter. Int J Syst Evol Microbiol 2008;58:790-797.

23. Katoh K, Rozewicki J, Yamada KD. MAFFT online service: multiple sequence alignment, interactive sequence choice and visualization. Brief Bioinform 2017;1-7.

24. Saitou N, Nei M. The neighbor-joining method: a new method for reconstructing phylogenetic trees. Mol Biol Evol 1987;4:406-425.

25. Fitch WM. Toward defining the course of evolution: Minimum change for a specific tree topology. Syst Biol 1971;20:406-416.

26. Felsenstein J. Evolutionary trees from DNA sequences: A maximum likelihood approach. J Mol Evol 1981;17:368-376.

27. Tamura K, Stecher G, Peterson D, Filipski A, Kumar S. MEGA6: Molecular evolutionary genetics analysis version 6.0. Mol Biol Evol 2013;30:2725-2729.

28. Kimura M. A simple method for estimating evolutionary rates of base substitutions through comparative studies of nucleotide sequences. J Mol Evol 1980;16:111-120.

29. Trifinopoulos J, Nguyen LT, von Haeseler A, Minh BQ. W-IQ-TREE: a fast online phylogenetic tool for maximum likelihood analysis. Nucleic Acids Res 2016;44:W232- 
W235.

492

493

494

495

496

497

498

499

500

501

502

503

504

505

506

507

508

509

510

30. Nei M, Kumar S. Molecular Evolution and Phylogenetics. New York: Oxford University Press.; 2000.

31. Felsenstein J. Confidence limits on phylogenies: an approach using the bootstrap. Evolution (N Y) 1985;39:783-791.

32. Yoon SH, Ha SM, Kwon S, Lim J, Kim Y, et al. Introducing EzBioCloud: A taxonomically united database of $16 \mathrm{~S}$ rRNA gene sequences and whole-genome assemblies. Int J Syst Evol Microbiol 2017;67:1613-1617.

33. Pearson W, Lipman D. Improved tools for biological sequence comparison. Proc Natl Acad Sci 1988;85:2444-2448.

34. Goris J, Konstantinidis KT, Klappenbach JA, Coenye T, Vandamme P, et al. DNA-DNA hybridization values and their relationship to whole-genome sequence similarities. Int J Syst Evol Microbiol 2007;57:81-91.

35. Figueras MJ, Beaz-Hidalgo R, Hossain MJ, Liles MR. Taxonomic affiliation of new genomes should be verified using average nucleotide identity and multilocus phylogenetic analysis. Genome Announc 2014;2:2-3.

36. Chun J, Oren A, Ventosa A, Christensen H, Arahal DR, et al. Proposed minimal standards for the use of genome data for the taxonomy of prokaryotes. Int J Syst Evol Microbiol 2018;68:461-466.

37. Auch AF, von Jan M, Klenk HP, Göker M. Digital DNA-DNA hybridization for microbial species delineation by means of genome-to-genome sequence comparison. Stand Genomic Sci 2010;2:117-134. 
38. Meier-Kolthoff JP, Auch AF, Klenk HP, Göker M. Genome sequence-based species delimitation with confidence intervals and improved distance functions. $B M C$ Bioinformatics;14. Epub ahead of print 2013. DOI: 10.1186/1471-2105-14-60.

39. Meier-Kolthoff JP, Göker M, Spröer C, Klenk HP. When should a DDH experiment be mandatory in microbial taxonomy? Arch Microbiol 2013;195:413-418.

40. Chernysheva N, Bystritskaya E, Stenkova A, Golovkin I, Nedashkovskaya O, et al. Comparative genomics and CAZyme genome repertoires of marine Zobellia amurskyensis KMM 3526T and Zobellia laminariae KMM 3676T. Mar Drugs;17. Epub ahead of print 2019. DOI: 10.3390/md17120661.

41. Vallenet D, Belda E, Calteau A, Cruveiller S, Engelen S, et al. MicroScope - An integrated microbial resource for the curation and comparative analysis of genomic and metabolic data. Nucleic Acids Res 2013;41:636-647.

42. Lombard V, Golaconda Ramulu H, Drula E, Coutinho PM, Henrissat B. The carbohydrate-active enzymes database (CAZy) in 2013. Nucleic Acids Res 2014;42:490-495.

43. Richter M, Rosselló-Móra R. Shifting the genomic gold standard for the prokaryotic species definition. Proc Natl Acad Sci U S A 2009;106:19126-19131.

44. Auch AF, Klenk HP, Göker M. Standard operating procedure for calculating genome-to-genome distances based on high-scoring segment pairs. Stand Genomic Sci 2010;2:142-148.

45. Naretto A, Fanuel M, Ropartz D, Rogniaux H, Larocque R, et al. The agar-specific hydrolase $\mathrm{ZgAgaC}$ from the marine bacterium Zobellia galactanivorans defines a new 
GH16 protein subfamily. J Biol Chem 2019;294:6923-6939.

536 46. Barbeyron T, Thomas F, Barbe V, Teeling H, Schenowitz C, et al. Habitat and

537

538

539

540

541 taxon as driving forces of carbohydrate catabolism in marine heterotrophic bacteria: Example of the model algae-associated bacterium Zobellia galactanivorans Dsij ${ }^{\mathrm{T}}$. Environ Microbiol 2016;18:4610-4627.

47. Ficko-Blean E, Préchoux A, Thomas F, Rochat T, Larocque R, et al. Carrageenan catabolism is encoded by a complex regulon in marine heterotrophic bacteria. Nat Commun;8. Epub ahead of print 2017. DOI: 10.1038/s41467-017-01832-6.

48. Thomas F, Lundqvist LCE, Jam M, Jeudy A, Barbeyron T, et al. Comparative characterization of two marine alginate lyases from Zobellia galactanivorans reveals distinct modes of action and exquisite adaptation to their natural substrate. J Biol Chem 2013;288:23021-37.

49. Thomas F, Barbeyron T, Tonon T, Génicot S, Czjzek M, et al. Characterization of the first alginolytic operons in a marine bacterium: from their emergence in marine Flavobacteriia to their independent transfers to marine Proteobacteria and human gut Bacteroides. Environ Microbiol 2012;14:2379-94. 
Table 1. Phenotypic characteristics of strains Asnod1-F08 ${ }^{\mathrm{T}}$, Asnd2-B02-B, Asnod2-B07-B ${ }^{\mathrm{T}}$, Asnod3-E08-A and of two Zobellia species used as related type strains.

1, Strain Asnod1-F08 ${ }^{\mathrm{T}}$ (Zobellia roscoffensis sp. nov.); 2, Asnd2-B02-B (Zobellia roscoffensis sp. nov.); 3, Asnod2-B07-B ${ }^{\mathrm{T}}$ (Zobellia nedashkovskayae sp. nov.); 4, Asnod3-E08-A (Zobellia nedashkovskayae sp. nov.); 5, Zobellia amurskyensis KMM 3526 ; 6, Zobellia laminariae KMM $3676^{\mathrm{T}}$. Cells of all strains share the following characteristics: Gram-negative, aerobic, heterotroph, chemorganotroph with respiratory metabolism, gliding motility, do not form endospores, do not accumulate poly- $\beta$-hydroxybutyrate as an intracellular reserve product; require $\mathrm{Na}^{+}$ion or seawater for growth. All strains are positive for flexirubin production and nitrate reduction; for the utilization as sole carbon source of D-glucose, D-galactose, D-fructose, rhamnose, sucrose, D-maltose, lactose, L-arabinose, mannose, xylose, mannitol, and porphyrin; for the hydrolysis of DNA, aesculin and Tween 20; for acid and alkaline phosphatase, esterase lipase (C8), leucine, valine and cystine arylamidases, trypsin, $\alpha$ - and $\beta$-glucosidase, $\beta$-galactosidase (PNPG test), oxidase and catalase activities; for the acid production from D-glucose, D-galactose, D-fructose, mannose, rhamnose, Dxylose and D-maltose. All strains are negative for indole production; for utilization of caprate, adipate, citrate, gluconate, malate, phenylacetate, glucomannan, galactomannan, arabinan, xyloglucan, agar, $\kappa-, 1$ - and $\lambda$-carrageenan and pectin; for the hydrolysis of $\kappa$ - and 1 -carrageenan; for urease, Lipase $(\mathrm{C} 14)$ and $\alpha$-fucosidase activities; for the acid production from L-sorbose, Dmelezitose, L-xylose, methyl-D-xylopyranoside, adonitol, L-arabitol, dulcitol, erythritol, xylitol, gentiobiose, raffinose, inulin, starch, glycogen, gluconate, 2-ketogluconate and 5-ketogluconate. +, Positive; -, negative; W, weakly positive; NA, not available.

\begin{tabular}{|c|c|c|c|c|c|c|}
\hline Characteristic & 1 & 2 & 3 & 4 & 5 & 6 \\
\hline \multicolumn{7}{|l|}{ Growth conditions: } \\
\hline Optimum temperature $\left({ }^{\circ} \mathrm{C}\right)$ & $25-30$ & $25-30$ & $25-30$ & $25-30$ & $23-25 \dagger$ & $21-23 \dagger$ \\
\hline Temperature range $\left({ }^{\circ} \mathrm{C}\right)$ & $4-40$ & $4-37$ & $4-40$ & $4-40$ & $4-32 \dagger$ & $4-30 \dagger$ \\
\hline Optimum pH & 7.5 & 7.5 & 7.5 & 7.5 & NA & NA \\
\hline $\mathrm{pH}$ range & $5.5-8.5$ & $5.5-8.5$ & $5.5-8.0$ & $5.5-8.0$ & NA & NA \\
\hline $\mathrm{NaCl}$ range $(\%)$ & $2-6$ & $2-6$ & $3-6$ & $3-4$ & $1-6 \dagger$ & $1.5-6 \dagger$ \\
\hline Optimum $\mathrm{NaCl}(\%)$ & 2 & 2 & 2 & 2 & $2 \dagger$ & $2 \dagger$ \\
\hline Iridescence & w & w & - & - & - & - \\
\hline \multicolumn{7}{|l|}{ Enzyme (API $20 \mathrm{NE}$ ) } \\
\hline Arginine dihydrolase & - & - & - & - & + & - \\
\hline Gelatinase & - & + & - & - & + & + \\
\hline \multicolumn{7}{|l|}{ Hydrolysis of: } \\
\hline Starch (lugol assay) & - & - & - & - & + & - \\
\hline Agar (lugol assay) & + & + & - & - & + & - \\
\hline Alginic acid & - & - & + & + & + & - \\
\hline Tween 40 & - & - & + & + & - & - \\
\hline Tween 60 & + & - & + & + & + & - \\
\hline Tween 80 & + & + & + & - & - & - \\
\hline
\end{tabular}




\begin{tabular}{|c|c|c|c|c|c|c|}
\hline \multicolumn{7}{|l|}{ Acid production } \\
\hline Glycerol & - & - & - & - & + & + \\
\hline D-arabinose & + & + & - & - & + & + \\
\hline L-arabinose & - & - & + & + & + & + \\
\hline D-ribose & - & - & - & - & + & + \\
\hline Inositol & - & - & - & - & + & + \\
\hline D-mannitol & - & - & + & + & + & + \\
\hline D-sorbitol & - & - & - & - & + & + \\
\hline Methyl-D-mannopyranoside & + & + & + & + & + & - \\
\hline Methyl-D-glucopyranoside & + & + & + & + & + & - \\
\hline N-acetyl-glucosamine & + & + & + & + & - & - \\
\hline Amygdaline & + & + & + & + & + & - \\
\hline Arbutine & + & + & + & + & - & - \\
\hline Salicine & + & + & + & + & - & - \\
\hline D-cellobiose & + & + & + & + & w & - \\
\hline D-lactose & + & + & + & + & + & - \\
\hline D-melibiose & + & + & - & - & + & + \\
\hline D-sucrose & + & + & + & + & + & - \\
\hline D-trehalose & + & + & + & + & + & - \\
\hline D-turanose & + & + & + & + & + & - \\
\hline D-lyxose & + & + & + & + & + & - \\
\hline D-tagatose & + & + & - & - & + & - \\
\hline D-fucose & - & - & - & - & + & + \\
\hline L-fucose & + & + & - & - & + & + \\
\hline D-arabitol & - & - & - & - & + & - \\
\hline \multicolumn{7}{|l|}{ Utilization of } \\
\hline N-acetyl-glucosamine & + & + & - & - & + & + \\
\hline L-fucose & $\mathrm{w}$ & + & w & $\mathrm{w}$ & + & - \\
\hline Raffinose & + & + & + & - & + & + \\
\hline Amylopectine & - & - & - & - & + & - \\
\hline Laminarin & - & - & + & + & + & w \\
\hline Lichenin & $\mathrm{w}$ & w & - & - & w & w \\
\hline Arabinoxylan & - & - & - & - & + & - \\
\hline Fucoidin & - & - & + & + & + & w \\
\hline Xylan & + & + & - & - & + & - \\
\hline Ulvan & $\mathbf{w}$ & w & $\mathrm{w}$ & + & + & w \\
\hline Alginic acid & - & - & + & + & w & $\mathbf{w}$ \\
\hline \multicolumn{7}{|l|}{ Enzymes (API ZYM) } \\
\hline$\alpha$-Chymotrypsin & - & - & + & + & - & - \\
\hline Naphtol phosphohydrolase & + & + & w & + & + & + \\
\hline$\alpha$-galactosidase & - & + & - & - & + & - \\
\hline
\end{tabular}




\begin{tabular}{|lcccccc|}
\hline$\beta$-glucuronidase & - & - & - & - & - & - \\
N-acetyl- $\beta$-glucosaminidase & - & + & - & - & + & + \\
$\alpha$-mannosidase & - & + & - & - & + & - \\
DNA G+C mol \% & 3736.56 & 37.7 & 37.6936 .8 & 336781 & 38.1 & 36.686 .8 \\
\hline
\end{tabular}

38.09

$\dagger$ Data from Nedashkovskaya [2] 
Table 2. Cellular fatty acid composition of Zobellia species studied.

Strains: 1, Asnod 1-F08 ${ }^{\mathrm{T}}$ (Zobellia roscoffensis sp. nov.); 2, Asnod2-B02-B (Z. roscoffensis sp. nov.); 3, Asnod2-B07-B ${ }^{\mathrm{T}}$ (Z. nedashkovskayae sp. nov); 4, Asnod3-E08-A ${ }^{\mathrm{T}}$ (Z.

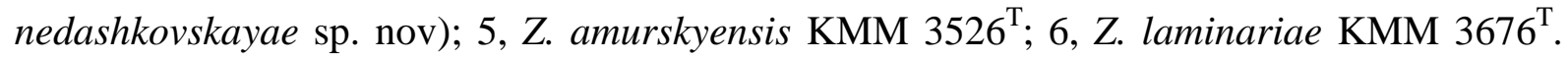
Data are percentages of the total fatty acids. Fatty acids that represented $<1.0 \%$ in the six strains were omitted. Fatty acids that represented $>10.0 \%$ are indicated in bold. -, Fatty acids not detected or below $1 \%$.

\begin{tabular}{|c|c|c|c|c|c|c|}
\hline Fatty acid & $\mathbf{1}$ & 2 & 3 & 4 & 5 & 6 \\
\hline \multicolumn{7}{|l|}{ Straight-chain } \\
\hline $\mathrm{C}_{14: 0}$ & 1.0 & 1.0 & - & - & 1.5 & 1.0 \\
\hline $\mathrm{C}_{15: 0}$ & 7.5 & 8.0 & 8.6 & 9.3 & 6.5 & 10.3 \\
\hline $\mathrm{C}_{15: 1} \omega 6 c$ & 1.0 & 1.0 & 1.7 & 1.8 & 1.2 & 1.1 \\
\hline $\mathrm{C}_{16: 0}$ & - & 1.0 & - & - & - & 1.0 \\
\hline $\mathrm{C}_{16: 0} 3-\mathrm{OH}$ & 1.2 & 1.0 & 1.1 & 1.0 & 1.6 & 1.4 \\
\hline $\mathrm{C}_{17: 1} \omega 6 c$ & - & - & 1.0 & 1.0 & - & - \\
\hline $\mathrm{C}_{18: 1} \omega 5 c$ & - & - & 1.5 & 1.4 & 1.0 & 1.0 \\
\hline \multicolumn{7}{|c|}{ Branched chain } \\
\hline iso- $\mathrm{C}_{15: 0}$ & 26.7 & 25.2 & 20.9 & 22.6 & 29.5 & 25.6 \\
\hline iso- $\mathrm{C}_{15: 0} 3-\mathrm{OH}$ & 3.2 & 3.1 & 3.6 & 3.4 & 3.0 & 2.8 \\
\hline anteiso- $\mathrm{C}_{15: 0}$ & - & - & 1.3 & 1.4 & 1.7 & 1.5 \\
\hline iso- $\mathrm{C}_{15: 1} \mathrm{G}$ & 12.9 & 12.2 & 10.7 & 12.3 & 11.8 & 9.4 \\
\hline iso- $\mathrm{C}_{17: 0} 3-\mathrm{OH}$ & 19.8 & 20.3 & 21.2 & 18.8 & 15.4 & 18.7 \\
\hline iso- $\mathrm{C}_{17: 1} \omega 9 c$ & 6.3 & 7.3 & 7.9 & 7.7 & 4.7 & 5.6 \\
\hline \multicolumn{7}{|c|}{ Summed features* } \\
\hline 3 & 10.7 & 10.9 & 13.8 & 12.9 & 14.9 & 14.2 \\
\hline 4 & 1.0 & 1.0 & 1.0 & 1.0 & 1.0 & - \\
\hline \multicolumn{7}{|l|}{ ECL $\dagger$} \\
\hline 13.565 & 2.7 & 2.8 & 1.4 & 1.3 & 1.6 & 1.4 \\
\hline 16.582 & 1.2 & 1.2 & 1.2 & 1.2 & 1.0 & 1.0 \\
\hline
\end{tabular}

* Summed feature 3 contained $\mathrm{C}_{16: 1} \omega 7 c$ and/or iso- $\mathrm{C}_{15: 0} 2 \mathrm{OH}$; summed feature 4 contained iso- $\mathrm{C}_{17: 1} \mathrm{I}$ and/or anteiso- $\mathrm{C}_{17: 1} \mathrm{~B}$.

$\dagger$ ECL, Equivalent chain-length. The identity of the fatty acid is not known 


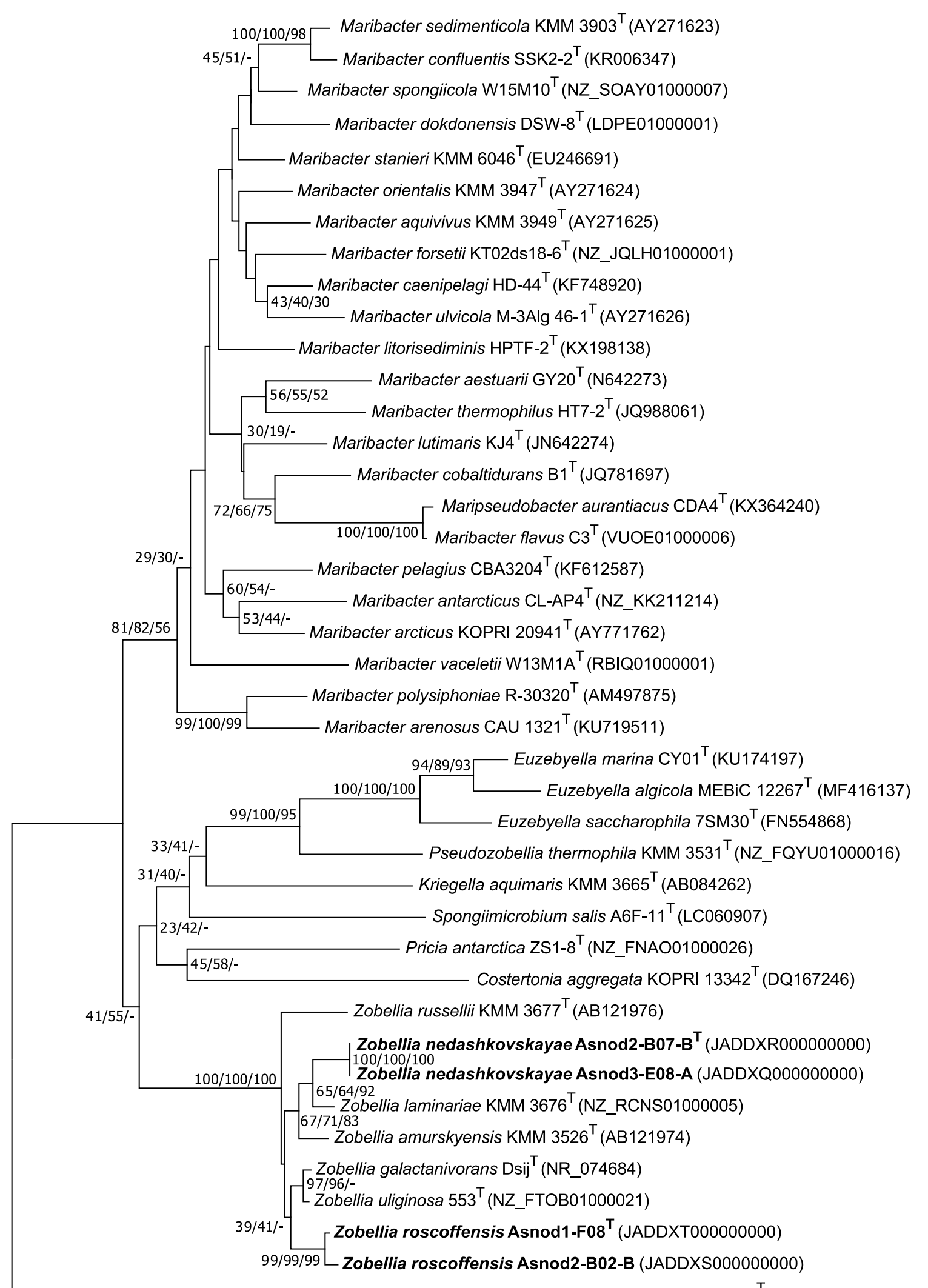

Flavobacterium aquatile $\mathrm{F}^{3} 6^{\top}$ (JRHH01000003)

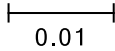


Fig. 1. Neighbour-joining tree based on $16 \mathrm{~S}$ rRNA gene sequences, showing the phylogenetic relationships between strains Asnod1-F08 ${ }^{\mathrm{T}}$, Asnod2-B02-B, Asnod2-B07-B ${ }^{\mathrm{T}}$, Asnod3-E08-A and related taxa from the family Flavobacteriaceae. Numbers at the nodes indicate bootstrap values (in percentage of 1000 replicates) in neighbour-joining, maximum-likelihood and maximum-parsimony analyses respectively, while dashes instead of numbers indicate that the node was not observed in the corresponding analysis. For nodes conserved in at least two trees, all bootstrap values are shown. Nodes without bootstrap value are not conserved in other trees and $<70 \%$. Flavobacterium aquatile $\mathrm{F}^{2} 6^{\mathrm{T}}$ was used as antgroup. Bar, 0.01 changes per nucleotide position. 
Supplementary Table S1: Properties of the draft genomes obtained for the four studied strains.

\begin{tabular}{|c|c|c|c|c|}
\hline Strain & Asnod1-F08 $^{\mathrm{T}}$ & Asnod2-B02-B & Asnod2-B07-B $^{\mathrm{T}}$ & Asnod3-E08-A \\
\hline Species & Z. roscoffensis & Z. roscoffensis & Z. nedashkovskayae & Z. nedashkovskayae \\
\hline Genome accession & JADDXT000000000 & JADDXS000000000 & JADDXR000000000 & JADDXQ000000000 \\
\hline Draft genome length (b) & $4,979,074$ & $5,012,136$ & $4,941,018$ & $5,025,849$ \\
\hline Number of contigs & 6 & 11 & 5 & 13 \\
\hline Number of scaffolds & 2 & 6 & 3 & 9 \\
\hline Estimated completeness & $100 \%$ & $100 \%$ & $100 \%$ & $100 \%$ \\
\hline N50 & $1,935,264$ & $1,275,558$ & $2,631,201$ & $1,255,004$ \\
\hline Paired sequencing reads & $5,312,862$ & $5,534,396$ & $4,493,736$ & $2,037,244$ \\
\hline Total sequencing data (b) & $1,259,406,978$ & $1,360,453,660$ & $1,105,016,829$ & $464,679,866$ \\
\hline Estimated coverage & $253 \mathrm{X}$ & $271 \mathrm{X}$ & $224 \mathrm{X}$ & $92 X$ \\
\hline $\mathrm{G}+\mathrm{C}$ content & $37.56 \%$ & $37.69 \%$ & $36.81 \%$ & $36.68 \%$ \\
\hline Number of CDS & 4,199 & 4,205 & 4,290 & 4,412 \\
\hline
\end{tabular}




\section{Supplementary Table S2}

Pairwise nucleotide comparisons (in percentage of similarity sequence) between Zobellia species 16S rRNA gene sequences.

\begin{tabular}{|c|c|c|c|c|c|c|c|c|c|c|}
\hline & & 1 & & & & & & & & \\
\hline Zobellia roscoffensis Asnod1-F08 ${ }^{\mathrm{T}}$ & 1 & 100 & 2 & & & & & & & \\
\hline Z. roscoffensis Asnod2-B02-B & 2 & 99.7 & 100 & 3 & & & & & & \\
\hline Z. nedashkovskayae Asnod2-B07-B ${ }^{\mathrm{T}}$ & 3 & 97.8 & 98.0 & 100 & 4 & & & & & \\
\hline Z. nedashkovskayae Asnod3-E08-A & 4 & 97.8 & 98.0 & 100 & 100 & 5 & & & & \\
\hline Z. amurskyensis KMM $3526^{\mathrm{T}}$ & 5 & 98.5 & 98.3 & 98.5 & 98.5 & 100 & 6 & & & \\
\hline Z. laminariae KMM $3676^{\mathrm{T}}$ & 6 & 98.2 & 97.9 & 99.1 & 99.1 & 99.3 & 100 & 7 & & \\
\hline Z. galactanivorans $\mathrm{Dsij}^{\mathrm{T}}$ & 7 & 99.0 & 98.8 & 98.1 & 98.1 & 99.0 & 98.5 & 100 & 8 & \\
\hline Z. russellii $\mathrm{KMM} 3677^{\mathrm{T}}$ & 8 & 98.0 & 97.7 & 97.4 & 97.4 & 98.4 & 97.9 & 98.4 & 100 & 9 \\
\hline Z. uliginosa $553^{\mathrm{T}}$ & 9 & 99.0 & 98.8 & 97.9 & 97.9 & 98.9 & 98.4 & 99.8 & 98.4 & 100 \\
\hline
\end{tabular}




\section{Supplementary Table S3}

Whole genome relatedness analysis (in percentage) of strains Asnod1-F08 ${ }^{\mathrm{T}}$, Asnod2-B02-B, Asnod2-B07-B ${ }^{\mathrm{T}}$, Asnod3-E08-A and Zobellia species for which whole genome sequences are available.

Average nucleotide identities (ANI) are shown below the diagonal and genome-to-genome distance calculations (GGDC) are shown above the diagonal. GGDC values were calculated online (http://ggdc.dsmz.de/distcalc2.php) and the results from formula 2 were used. ANI values were calculated with an online program (http://jspecies.ribohost.com/jspeciesws/\#analyse). The GenBank accession numbers for the whole genome sequences are given in the top row.

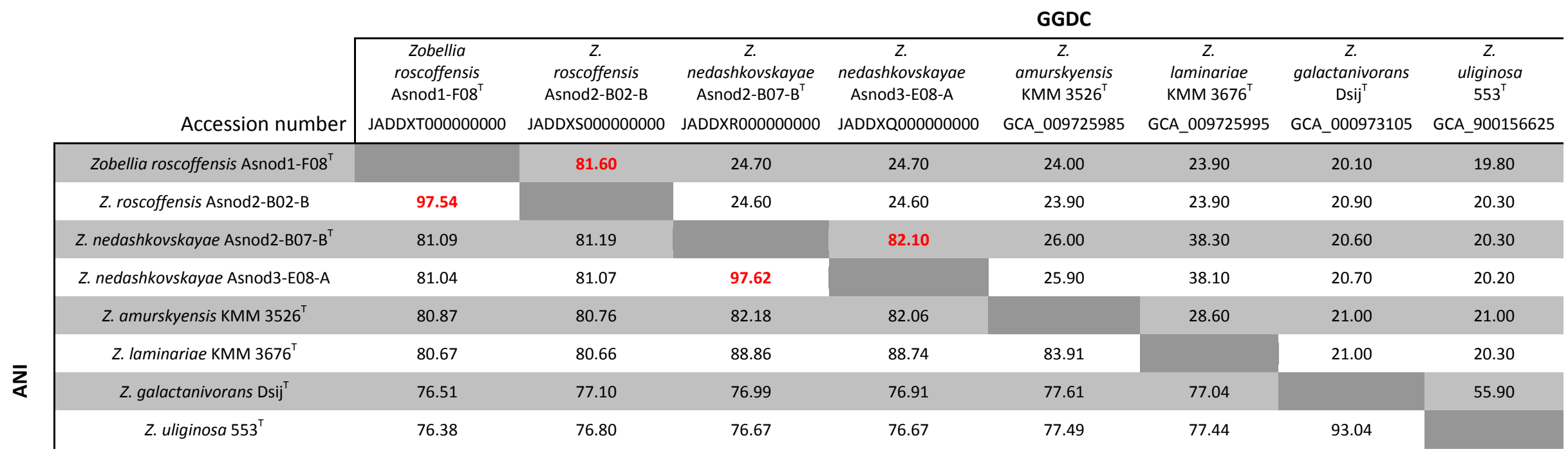

The percentages in red indicate the values above the thresholds of species boundary (95\% for ANI and $70 \%$ for GGDC). 


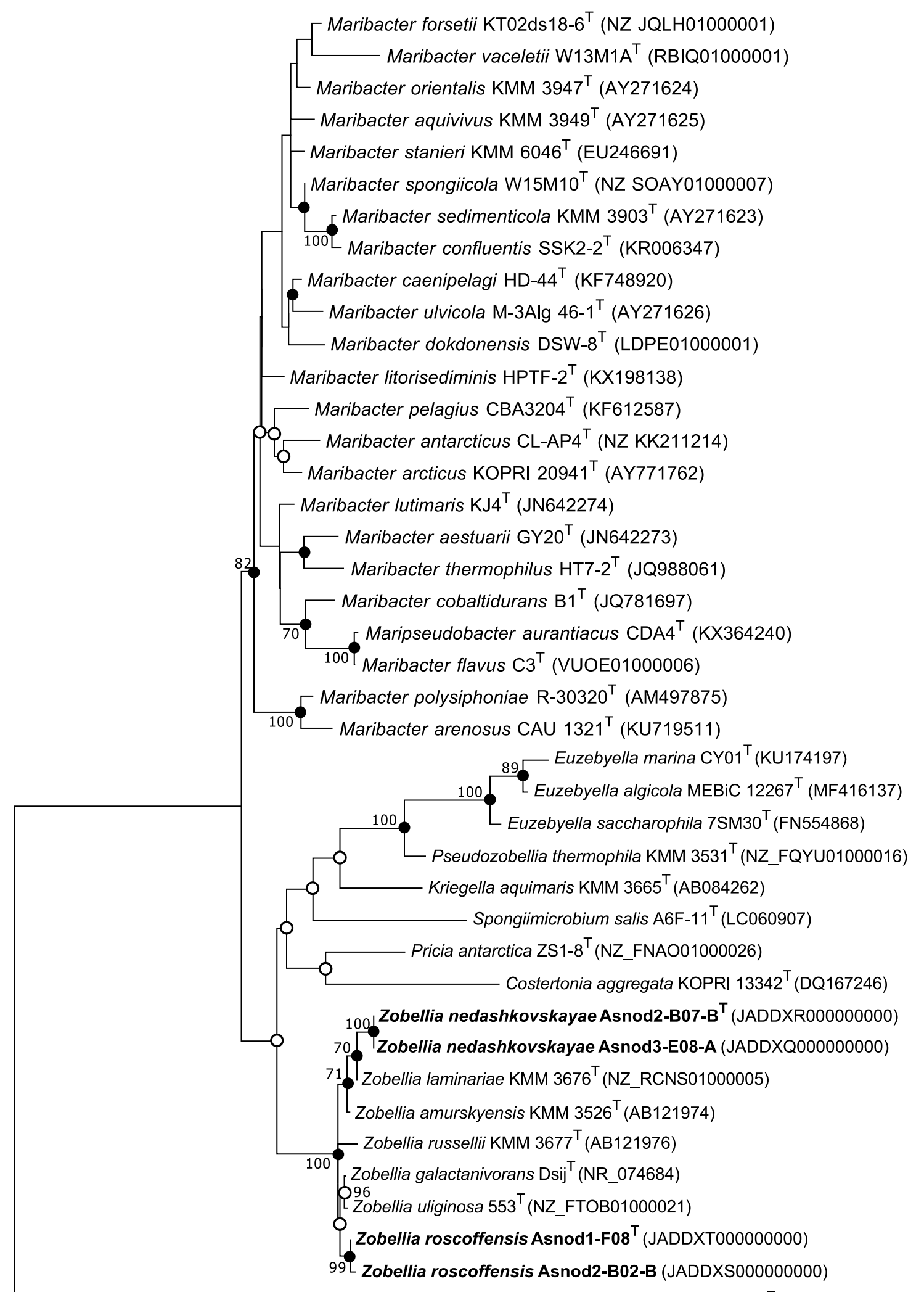
Flavobacterium aquatile $\mathrm{F} 36^{\top}$ (JRHH01000003) 


\section{Supplementary Fig. S1}

Maximum-likelihood (ML) tree based on 16S rRNA gene sequences, showing the phylogenetic relationships between strains Asnod1-F08 ${ }^{\mathrm{T}}$, Asnod2-B02-B, Asnod2-B07-B ${ }^{\mathrm{T}}$, Asnod3-E08-A and related taxa from the family Flavobacteriaceae. Numbers at nodes are bootstrap values shown as percentages of 1000 replicates; only values $>70 \%$ are shown. Filled circles indicate that the corresponding nodes were also recovered in the trees generated with the neighbour-joining (NJ) and maximum-parsimony algorithms, while open circles indicate that the nodes were only recovered in the tree generated with the $\mathrm{NJ}$ and ML algorithms. Flavobacterium aquatile $\mathrm{F} 6^{\mathrm{T}}$ was used as an outgroup. Bar, 0.05 changes per nucleotide position. 


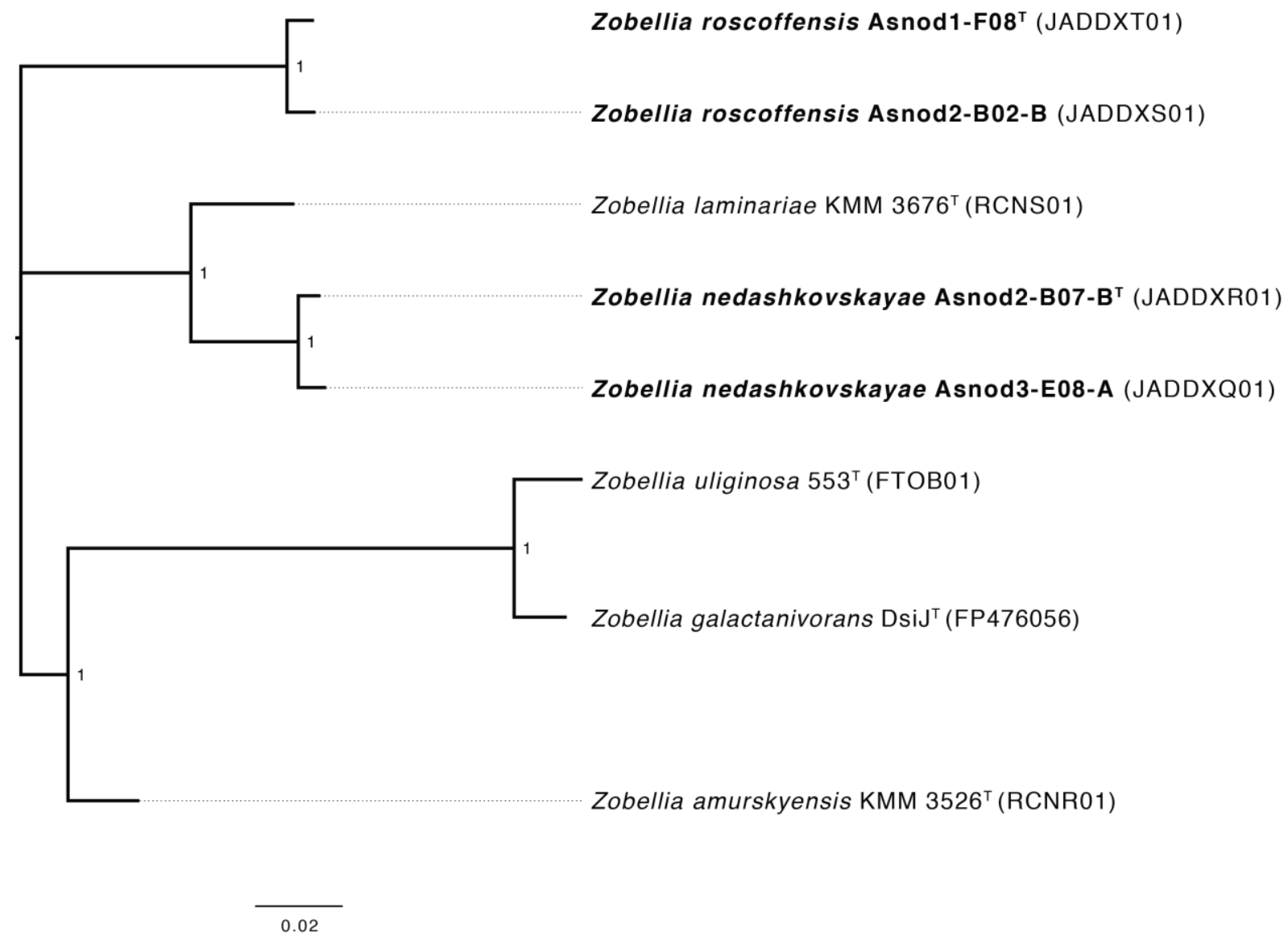

\section{Supplementary Figure S2}

Phylogenomic tree inferred with FastTree MP on a concatenated alignment of 2573 translated protein-coding genes of the core genome of Zobellia isolates with available complete or draft genomes (genome accessions are given in brackets). Bar: 0.02 change per position. 

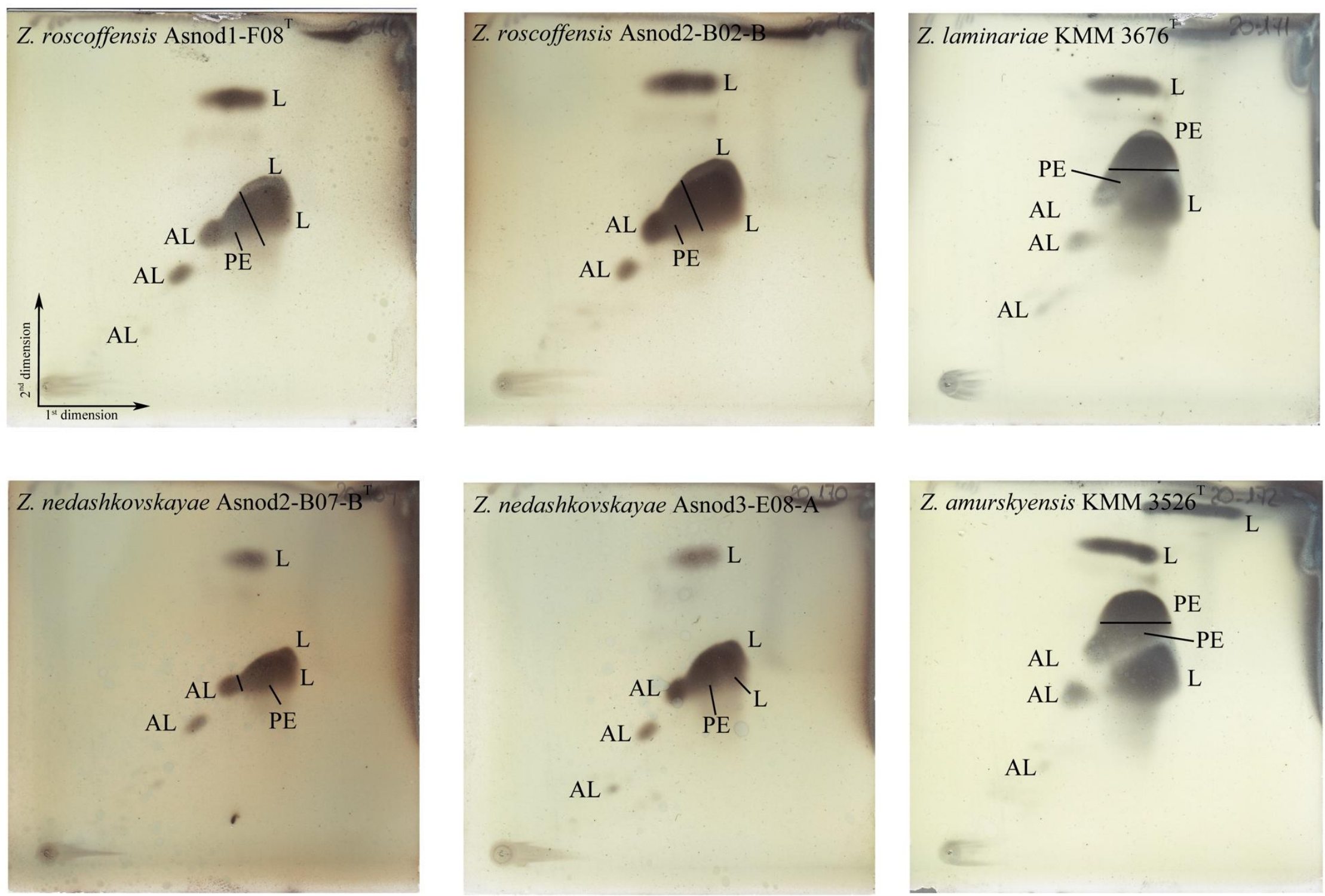

AL 


\section{Supplementary Fig. S3}

Two-dimensional thin layer chromatography of the polar lipids of strains Asnod1-F08 ${ }^{\mathrm{T}}$ and Asnod2-B02-B (Zobellia roscoffensis sp. nov.), Asnod2-B07-B ${ }^{\mathrm{T}}$ and Asnod3-E08-A (Z. nedashkovskayae sp. nov.), Z. amurskyensis KMM $3526^{\mathrm{T}}$ and Zobellia laminariae $\mathrm{KMM}^{3676^{\mathrm{T}}}$. The first dimension is developed in chloroform:methanol:water $(65: 25: 4, \mathrm{v} / \mathrm{v} / \mathrm{v})$, and the second in chloroform:methanol:acetic acid:water (80:12:15:4, v/v/v/v). AL, aminolipid; L, lipid; PE, phosphatidylethanolamine. 


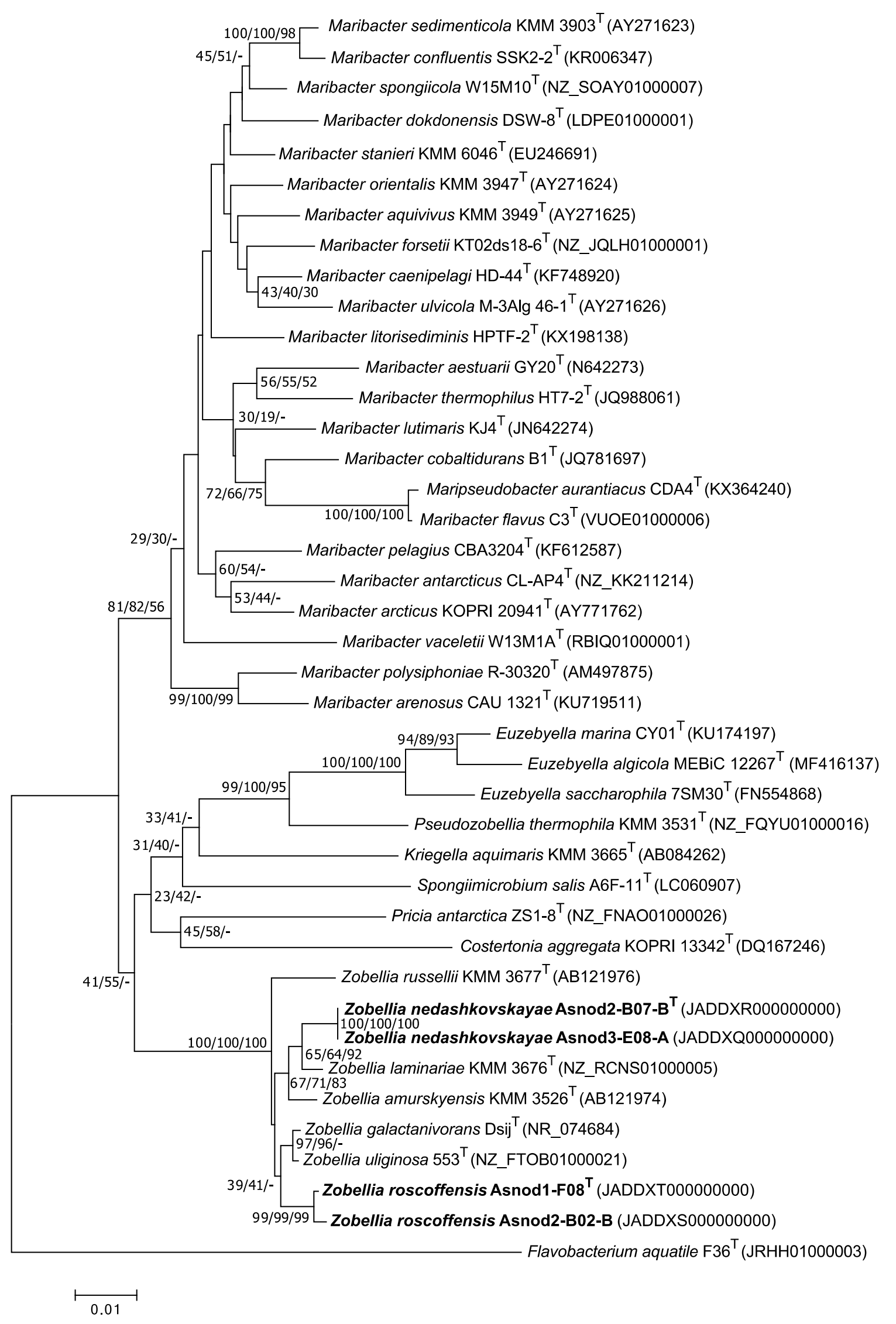




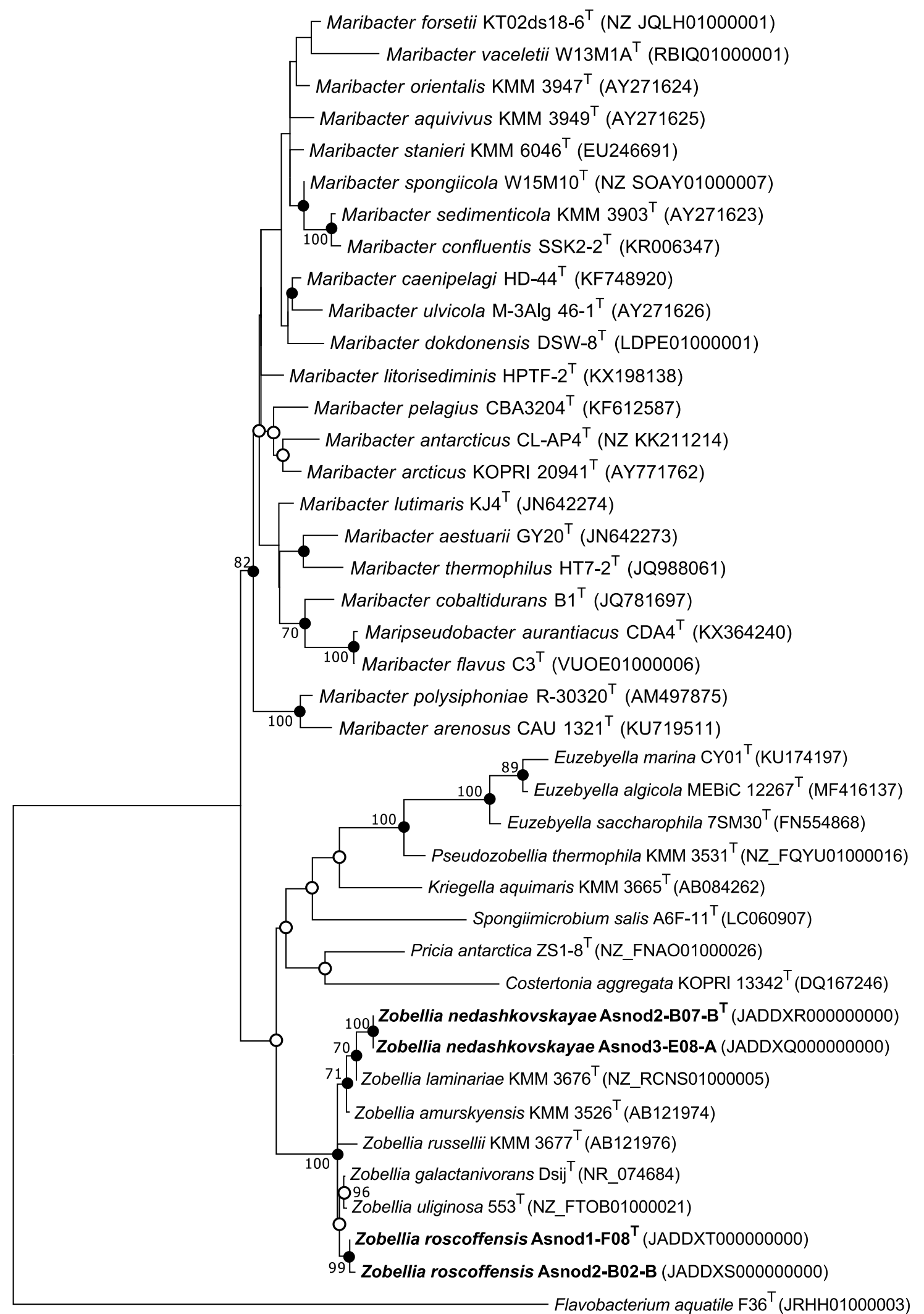
Flavobacterium aquatile $\mathrm{F} 36^{\top}{ }^{\top}$ (JRHH01000003) 